\title{
POTENSI PASANG SURUT LAHAN RAWA UNTUK PENGEMBANGAN IRIGASI DI KABUPATEN MERAUKE MENGGUNAKAN PEMODELAN HIDRODINAMIKA 1D2D
}

\section{POTENTIAL OF TIDAL LOWLAND FOR IRRIGATION DEVELOPMENT IN MERAUKE REGENCY USING HYDRODYNAMIC MODELLING 1D2D}

\author{
Yudi Lasmana') Parlinggoman Simanungkalit1) Muhammad Gifariyono' ${ }^{1)}$ \\ Ganggaya Sotyadarpita ${ }^{1)}$ Budi Triadi'2) \\ ${ }^{1)}$ Balai Litbang Rawa Jl. Gatot Subroto No. 6 Banjarmasin \\ ${ }^{2)}$ Balai Litbang Lingkungan Keairan, JI. Ir. H. Juanda No. 193 Bandung
}

\begin{abstract}
ABSTRAK
Kabupaten Merauke mempunyai tiga sungai besar yaitu Sungai Bian, Sungai Kumbe dan Sungai Maro (BIKUMA), ketiga sungai tersebut mempunyai potensi pasang surut horisontal yang besar. Untuk pengembangan lahan irigasi rawa diperlukan kajian potensi pasang surut. Kajian ini didukung dengan survei hidrometri dan hidrolika yang dilakukan pada musim kemarau saat spring tide dan neap tide secara bersamaan untuk ketiga sungai. Survei meliputi aktivitas pengukuran geometri sungai dengan rentang per 5 $\mathrm{km}$, pengukuran hidrometri sungai (pengamatan fluktuasi muka air dengan jarak proporsional untuk kalibrasi model dan kecepatan arus di hulu sungai untuk mendapatkan debit). Batasan pengukuran sungai bagian hulu dibatasi dengan jarak Sungai Bian 125 Km, Sungai Kumbe sepanjang 171 km, dan Sungai Maro sepanjang $66 \mathrm{~km}$ dari muara laut. Kemudian dilakukan pemodelan hidrodinamika Sobek 1D yang menguraikan pergerakan air dari hulu sampai ke hilir. Dari hasil pemodelan diketahui bahwa air yang masuk dari laut ke Sungai Bikuma lebih besar dibandingkan air yang keluar ke laut. Adapun potensi pasang surutnya sebesar 1,7 Milliar m³. Selanjutnya dilakukan simulasi Sobek 1D2D untuk mengetahui sejauh mana pada kondisi alami daerah yang dapat digenangi adalah 123.609 ha. Pemanfaatan potensi pasang surut tersebut dapat disalurkan ke zona pengembangan melalui sistem tata air irigasi rawa yang terintegrasi sehingga pemanfaatan air dapat optimal.
\end{abstract}

Kata kunci: Pemodelan hidrodinamika, pasang surut, irigasi, rawa, Sungai bian, Sungai kumbe, Sungai maro, Kabupaten Merauke, sobek.

\begin{abstract}
Merauke Regency has three major rivers i.e Bian River, Kumbe River and Maro River (BIKUMA), the three rivers have large horizontal tidal potential. To know the potential of tides in the development of lowland irrigation in Merauke Regency needs to be studied. This study is supported by hydrometry and hydraulic surveys which has been conducted during the dry season during at spring tide and neap tide simultaneously for all three rivers. The survey included measuring river geometry activities with a range of $5 \mathrm{Km}$, river hydrometry measurements (observation of water fluctuations with proportional distances for model calibration and upstream river velocity for discharge). Limitations of river upstream measurements are limited by the distance where the Bian River along $125 \mathrm{Km}$, the River Kumbe along $171 \mathrm{~km}$, and the Maro River along $66 \mathrm{~km}$ from the estuary. Then, performed a Sobek 1D hydrodynamic modeling that describes the movement of water from upstream into downstream. From the results of modeling is known that the water entering from the sea to the Bikuma River is greater than the water out to sea. The potential for tides is 1.7 Billion m3. Furthermore, the simulation of Sobek 1D2D to obtain the extent of natural condition, the area that can be inundated is $123.609 \mathrm{ha}$. Utilization of tidal potential can be channeled to the development zone through an integrated lowland irrigation water management system so that water utilization can be optimal.
\end{abstract}

Keywords: Hydrodynamic model, tidal, lowland, irrigation, Bian river, Kumbe river, Maro river, Merauke Regency, Sobek. 


\section{PENDAHULUAN}

Ketahanan pangan merupakan masalah yang belum dapat teratasi di Indonesia. Walaupun Indonesia disebut Negara agraris yang kaya akan pertaniannya, namun pada kenyataannya masih banyak terdapat kekurangan pangan di beberapa daerah dikarenakan semakin meningkatnya jumlah penduduk yang tidak dibarengi dengan penambahan lahan sawah. Pertambahan penduduk bukan menjadi satu satunya faktor yang menghambat ketahanan pangan nasional. Faktor serius lainnya adalah konversi lahan pertanian dan perubahan iklim yang menyebabkan gagal panen di beberapa daerah dan turunnya angka produksi pertanian. Menurut data BPS (2016), total luas lahan sawah di Indonesia tahun 2011 adalah \pm 8,09 juta ha,sedangkan menurut Las, et. al., (2007) angka konversi lahan dari tahun 2003 hingga tahun 2007 terjadi dengan kecepatan 110 ribu ha/tahun dan diprediksi 10 tahun hingga tahun 2017 luas konversi lahan yang diakibatkan oleh perbaikan tata ruang seluruh kabupaten di Indonesia mencapai 3 juta ha lahan produktif.

Ekstensifikasi pertanian merupakan usaha perluasan daerah pertanian dengan cara pembukaan lahan baru untuk pertanian. Salah satu lahan yang berpotensi dikembangkan adalah lahan rawa. Luas lahan rawa di Indonesia mencapai $\pm 33,4$ juta ha, sedangkan luas potensial yang dapat diusahakan untuk usaha pertanian mencapai $\pm 10,2$ juta ha, saat ini yang sudah dikembangkan pemerintah baru sekitar 1,31 juta ha (Alihamsyah, 2004).

Salah satu lokasi rawa yang berpotensi besar untuk dikembangkan adalah Kabupaten Merauke, Papua. Potensi lahan rawa di Kabupaten Merauke seluas 1.212.633,04 ha, dan hingga tahun 2015 baru dikembangkan kurang lebih seluas 40.000 ha (BWS Papua, 2015). Kabupaten Merauke merupakan salah satu dari 29 Kabupaten/ Kota di Provinsi Papua yang terletak di bagian selatan dan memiliki wilayah terluas di Provinsi Papua. Luas Kabupaten Merauke $45.071 \mathrm{Km}^{2}$ (11\% dari wilayah Provinsi). Sebagian besar wilayah Kabupaten Merauke terdiri dari daratan rendah dan berawa, dengan luas areal rawa $\pm 1.425 \mathrm{Km}^{2}$ dan daratan tinggi yang tersebar di beberapa kecamatan padalaman bagian utara. Merauke mempunyai karakteristik rawa dengan tunggang air pasang surut sebesar 5-7 $\mathrm{m}$, pengaruh air pasang laut masuk sampai sejauh 50-60 Km dan beberapa tempat terintrusi air asin/ air laut (BPS, 2016).

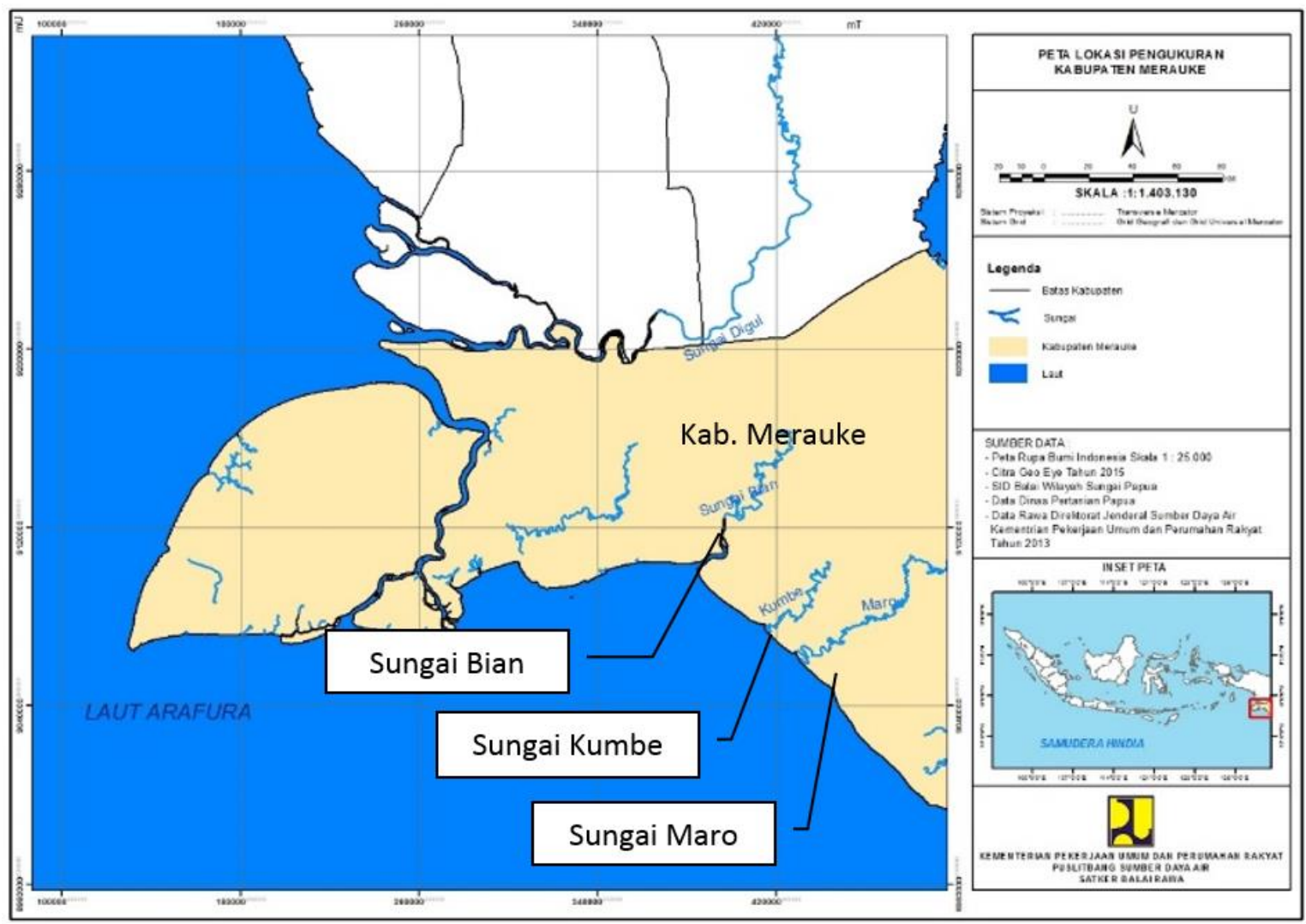

Gambar 1 Peta Lokasi Kegiatan 
Kabupaten Merauke mempunyai tiga sungai besar yaitu Sungai Bian, Sungai Kumbe dan Sungai Maro (lihat Gambar 1), ketiga sungai tersebut mempunyai potensi pasang surut horisontal yang besar. Oleh sebab itu maka perlu dilakukan penelitian terkait potensi sumber daya air ketiga sungai tersebut dalam mendukung pengembangan lahan irigasi di Merauke. Lebih jauh lagi studi fluktuasi muka air dan debit sepanjang sungai pasang surut sangat penting untuk manajemen sumber daya air ke depan.

Penelitian ini pertama kali menginformasikan tentang fakta bahwa pasang surut horizontal dapat mencapai lahan jika dilakukan rekayasa engineering. Walaupun sudah pernah dilakukan kajian hidrodinamika Model PENPAS Non Steady Flow di Sungai Maro Tahun 1982 dalam Laporan SKPB Irigation/Drainage Unit Irian Jaya (DPMA/ BTA60, 1982) kajian ini masih terbatas hidrodinamika di titik tertentu dan dengan teknologi pada masa itu belum dapat disimulasikan secara 2 Dimensi.

\section{KAJIAN PUSTAKA}

Pasang surut air laut adalah fenomena naik turunnya permukaan air laut disertai gerakan horisontal massa air yang terjadi secara periodik. Penyebab utamanya adalah pengaruh gravitasi bulan dan matahari. Gejala Pasut laut ini mudah dilihat secara visual dan dapat diamati sederhana dengan palem atau rambu pengamat pasut (gambar 2). Gerakan vertikal pasut menurut sifatnya dibagi dua yaitu :

1 Periodik yang disebabkan oleh pengaruh gravitasi bulan dan matahari.

2 Variasi Non-Pasut disebabkan oleh faktorfaktor non-astronomis yang mempengaruhi tinggi pasut yaitu kedalaman perairan, keadaan meteorologi, serta faktor hidrografis lainnya. (Lasmana, 2003)

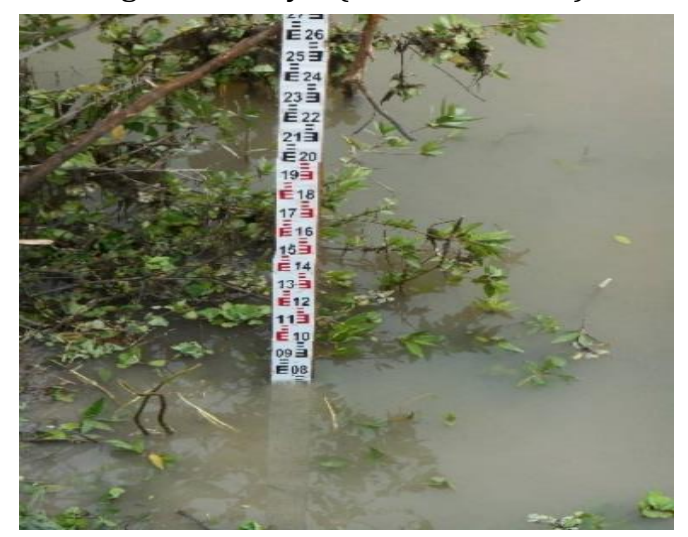

Sumber: Balai Litbang Rawa, 2016

Gambar 2 Pengamatan pasang surut dengan rambu ukur (peilschaal)
Pengaruh pasang surut air laut dapat dirasakan sampai jauh masuk kearah hulu dari muara sungai. Air yang berasal dari laut akan memasuki sungai pada saat pasang dan akan mengalir kembali ke laut pada saat surut. Bagian dari sungai pasang surut ini mempunyai debit air yang berubah-ubah sesuai dengan musim yang berlaku, dan sangat bergantung pada debit air yang berada pada bagian hulu sungai. Namun faktor yang paling berpengaruh pada sungai pasang surut adalah interksi antara gaya gravitasi bumi, bulan dan matahari, dimana pengaruh gravitasi bulan paling besar karena jarak lebih dekat dengan bumi. Ketinggian pasang surut dikenal dua macam yaitu :

1 Pasang purnama atau yang disebut spring tide yang terjadi karena superposisi gaya gravitasi bumi dan bulan pada saat purnama terhadap air laut sebagai ketinggian pasang maksimum

2 Pasang perbani atau disebut neap tide yang terjadi superposisi gaya gravitasi bumi dan bulan terhadap air laut pada kedudukan bulan perbani sebagai ketinggian pasang minimum. (Samuel, 2012)

Untuk mendapatkan potensi pasang surut di Sungai Bian, Maro dan Kumbe maka diperlukan suatu model pendekatan yang dapat mewakili keadaan alam yang sebenarnya. Mengingat rumitnya perhitungan hidrolika konvensional bila diaplikasikan pada bentuk penampang sungai tidak seragam dan perilaku aliran pasang surut bersifat tidak tunak maka diperlukan suatu simulasi model numerik hidraulik dengan perangkat lunak. Aplikasi perangkat dimaksudkan agar lebih dapat mewakili kondisi eksisting dengan ketelitian perhitungan dan analisa lebih terjaga (untuk mereduksi faktor "human error"). Pasang surut yang memasuki hulu sungai (Intertidal) mempunyai peran yang sangat signifikan dibandingkan dengan debit dari hulu sungai pada pemodelan hidrodinamika wilayah estuari (Brunner, 2008)

Program SOBEK digunakan untuk perhitungan aliran satu dimensi yang tidak tunak (Unsteady Flow). SOBEK adalah perangkat lunak modelling terintegrasi yang powerfull untuk peramalan banjir, optimasi sistem drainase, kontrol sistem irigasi, desain overflow saluran, morfologi sungai, intrusi air laut, dan kualitas air. Di samping itu operasi manual atau otomatis dari pompa, pintu air, bendungan, kolam penyimpanan, dan struktur lainnya dapat disimulasikan ke dalam model sehingga memberikan gambaran realistis tentang perilaku gerak air (Lasmana, 2013)

Pemodelan hidrodinamika di wilayah estuari yang dipengaruhi oleh pasang surut sudah 
banyak di aplikasikan di seluruh dunia dengan menggunakan software SOBEK diantaranya:

1 Aplication of Sobek Model in Yellow River Estuary (Ji, et al, 2003)

2 A Comparison Of Flood Extent Modelling Approaches Through Constraining Uncertainties On Gauge Data (Werner, 2004)

3 Hydrodynamics and Morphodynamics of Tidal Channels (Toffoloan, 2002)

4 Floodplain Inundation Simulation Using 2d Hydrodynamic Modelling Approach (Ruji, 2007)

5 Dll

Pemodelan hidrodinamika di sungai pasang surut yang pada umumnya besar dan pengaruh pasang surut mencapai ratusan kilometer memerlukan metode khusus pada aliran subkritis, aliran campuran (subkritis dan super kritis) atau transisi dari super kritis ke subkritis maka diperlukan perhatian khusus pada kekuatan dan efisiensi dari model matematik yang digunakan terutama untuk menjamin bahwa model stabil dan memenuhi hukum kontinuitas dan momentum (Aldrighetti, 2007). Menurut (Ji. et al, 2003) hasil analisis software Sobek mempunyai stabiltas yang baik dan dapat diterapkan di sungai pasang surut (estuari).

Kajian ini digunakan dua modul yaitu $S O B E K$ 1D Flow dan SOBEK Overlandflow 2D. 1D Flow modul untuk menghitung aliran 1 dimensi (tinggi muka air dan debit pada saluran terbuka) di sungai utama dan drainase. Overlandflow $2 D$ modul untuk menghitung pola genangan 2 dimensi pada lokasi kajian yang mana aliran $1 D$ telah overflow (lihat Gambar 2).

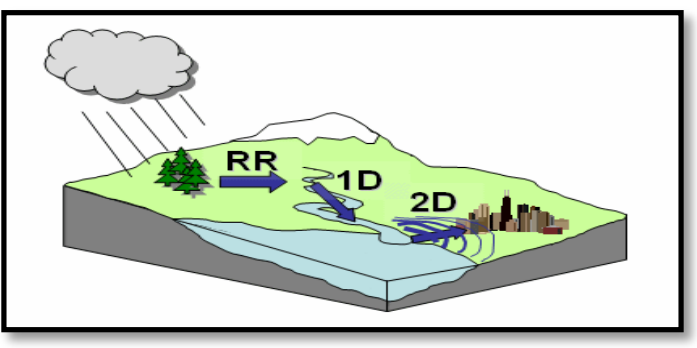

Sumber : Tutorial Sobek Rural, 2011

\section{Gambar 2 Pola Genangan pada SOBEK}

Simulasi mengenai kondisi lapangan aktual menghendaki informasi yang akurat mengenai dimensi sungai, aliran lateral serta penampungan tepi dan kekasaran hidrolik. Namun informasi ini jarang tersedia, sehingga perlu diperkirakan melalui model kalibrasi (membandingkan tinggi muka air dan debit aliran hasil simulasi dengan pengukuran).
Program SOBEK mensimulasikan aliran air dan tinggi muka air pada sistem saluran atas dasar dimensi-dimensi saluran yang sudah ada atau yang sedang direncanakan. Seluruh Program didasarkan pada persamaan diferensial parsial satu dimensi (1D) yang menggambarkan kondisi nyata aliran tidak tunak pada estuari (Toffoloan, 2002) (lihat Gambar 3). Persamaan tersebut merupakan translasi matematis dari hukumhukum kekekalan massa dan momentum yang dikenal sebagai persamaan Saint Venant, sebagai berikut:

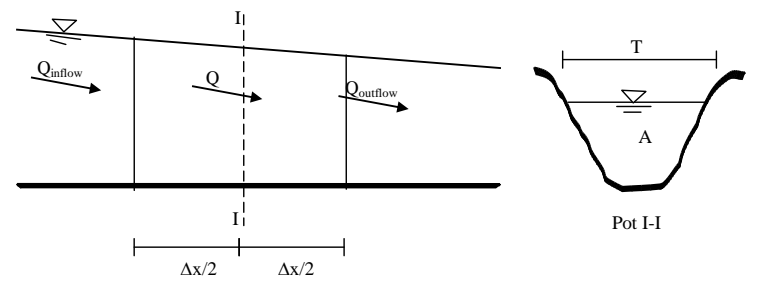

Sumber: Tuoi, 2008

Gambar 3 Sketsa Definisi Aliran yang Melewati Suatu Ruas Saluran

$\frac{\partial A_{f}}{\partial t}+\frac{\partial Q}{\partial x}=q_{l a t}$

$\frac{\partial Q}{\partial t}+\frac{\partial}{\partial x}\left(\frac{Q^{2}}{A_{f}}\right)+g A_{f} \frac{\partial \zeta}{\partial x}+g A_{f} \frac{Q|Q|}{K^{2}}-W_{f} \frac{\tau_{w i}}{\rho_{w}}=0 \ldots$ (2)

dimana:

$\mathrm{A}_{\mathrm{f}} \quad$ : luas potongan saluran basah $\left(\mathrm{m}^{2}\right)$

Q : debit $\left(\mathrm{m}^{3} /\right.$ det $)$

$\mathrm{q}_{\text {lat }} \quad$ : aliran samping (lateral) per satuan panjang saluran $\left(\mathrm{m}^{3} / \mathrm{det}\right)$

$\zeta \quad$ : tinggi muka air diatas referensi dataran horizontal (m)

$\mathrm{K}$ : daya angkut saluran

g : gaya gravitasi $\left(\mathrm{m} / \operatorname{det}^{2}\right)$

$\mathrm{W}_{\mathrm{f}}$ : lebar basah $(\mathrm{m})$

$\tau_{\mathrm{wi}} \quad$ : tegangan geser angin $\left(\mathrm{N} / \mathrm{cm}^{2}\right)$

$\rho_{\mathrm{w}} \quad$ : kepadatan air $\left(\mathrm{g} / \mathrm{cm}^{3}\right)$

$\mathrm{X}$ : posisi sepanjang poros saluran $(\mathrm{m})$

t : waktu (detik)

\section{Cross Section (Penampang Melintang Sungai)}

Data cross section berupa koordinat y-z dan total tampungan dari dihitung dengan menjumlah tampungan dari setiap sub-section (lihat Gambar 4). 

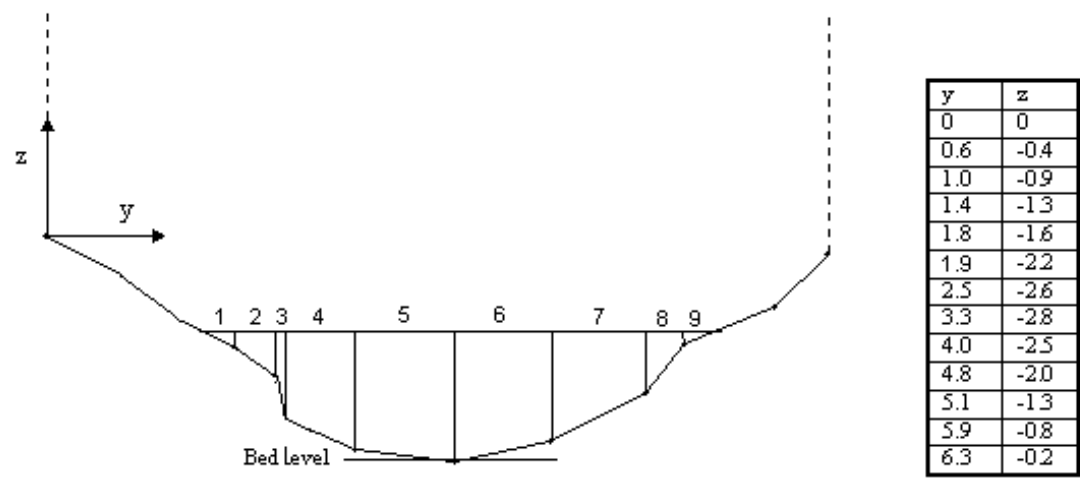

Gambar 4 Y-Z Cross Section pada SOBEK 1D dengan Sub-Seksi (Tutorial Sobek Rural, 2011)

Tampungan adalah kuantitas yang merepresentasikan kapasitas debit dari sungai pada setiap level muka air. Bahkan, menggabungkan nilai-nilai untuk gesekan dan radius hidraulik menjadi satu sebagai berikut:

$K_{i}=A_{i} C_{i} \sqrt{R_{i}}$

$K=$

$\sum_{i=1}^{n} K_{i}$

dimana:

Ki : daya angkut dari setiap subseksi dengan menerapkan kedalaman air dan gesekan

$\mathrm{K}$ : daya angkut total dari cross section

Ai : luas aliran yang masuk pada potongan sungai $\left(\mathrm{m}^{2}\right)$

Ci : koefisien Chezy ( $\mathrm{m}^{1 / 2} /$ detik)

Ri : jari-jari hidraulis dengan menerapkan kedalaman air (m)

i : nomor dari setiap subseksi (dihitung dari $\mathrm{y}=0)$

$\mathrm{n}$ : nomor subseksi

\section{METODOLOGI}

Kajian terhadap potensi pasang surut di Sungai Bian, Kumbe dan Maro meliputi aktivitas pengukuran hidrometri sungai (geometri sungai, fluktuasi muka air dan debit di hulu sungai, debit lateral). Pengukuran geometri sungai dilakukan dengan grid cross section per $5 \mathrm{Km}$ dan pengamatan muka air dilakukan dengan jarak tertentu di sepanjang sungai, untuk lebih jelasnya lihat Gambar 5. Pengukuran ke hulu dibatasi pada jarak $125 \mathrm{Km}$ dari muara untuk Sungai Bian, sepanjang $171 \mathrm{~km}$ untuk Sungai Kumbe, dan Sungai Maro sepanjang $66 \mathrm{~km}$.

Berdasarkan data primer tersebut yang dilaksanakan pada musim kemarau saat spring dan neap tide, yaitu pada periode tanggal 4 Agustus 2016 sampai dengan tanggal 10 Agustus 2016, kemudian dilakukan elaborasi dan evaluasi data sehingga tersaji data yang siap pakai. Selanjutnya dengan data tersebut dibuat simulasi dengan pemodelan matematik hidrodinamika $1 D$ yang menguraikan pergerakan air dari hulu sampai ke hilir pada ketiga sungai tersebut, namun pemodelan dibatasi pada kondisi batas (boundary condition) pemodelan. Kondisi batas hulu pada pemodelan Sungai Bian, Kumbe, dan Maro adalah debit aliran rata-rata selama 25 jam sedangkan kondisi batas hilir Sungai Bian, Kumbe dan Maro adalah fluktuasi pasang surut muka air di muara sungai. Pemodelan Kalibrasi dilakukan saat Neap di musim kemarau. Di samping itu terdapat kondisi batas internal di tempat-tempat pemasukan dan pengeluaran air pada sistem sungai yang merupakan representatif dari anakanak sungai eksisting (Triadi, L.B., 2013). Kondisi batas internal dibatasi pada tempat-tempat pemasukan debit aliran anak-anak sungai yang diperoleh dari data hujan satelit TRMM yang selanjutnya diproses menjadi debit aliran sungai dengan mengunakan model hujan aliran terdistribusi.

Pemodelan hidrodinamika Sungai Bian, Kumbe dan Maro dilakukan dengan metoda sebagai berikut:

1 Model Kalibrasi : Model Kalibrasi dilakukan dengan maksud untuk memperoleh model yang cukup representatif mewakili kondisi eksisting lapangan baik pada saat spring maupun neap tide. Kalibrasi dilakukan dengan membandingkan muka air hasil pemodelan dan muka air hasil pengamatan lapangan di sepanjang sungai. Saat simulasi model dilakukan, akan terjadi pergerakan air (muka air dan debit) dari kondisi batas hulu sampai 
dengan kondisi batas hilir. Pada saat proses kalibrasi, dicari nilai kekasaran sungai yang tidak diketahui sebelumnya. Koefisien kekasaran adalah kunci utama pemodelan numerik di saluran terbuka menjadi realistis sesuai kondisi lapangan, kesalahan estimasi kekasaran $50 \%$ berimplikasi pada eror 40\% di puncak debit. (Ballesteros, 2011). Proses kalibrasi dilakukan dengan menyesuiakan parameter model yang dilakukan berulangulang dengan cara trial and error, dan umumnya berlangsung cukup lama hingga diperoleh tinggi muka air dan kecepatan/debit yang mendekati dengan kondisi lapangan. Namun pada praktiknya kondisi ini agak sulit dicapai karena pemodelan dipengaruhi juga oleh ketelitian dari data primer yang digunakan, kondisi lokal dan faktor lain yang tak diketahui. Oleh karena itu akan ada nilai kesalahan dari model yang dihitung dengan menghitung standar deviasi antara muka air pengamatan dengan muka air simulasi, yaitu menggunakan metode Root Mean Square Error (RMSE) dengan fungsi sebagai berikut:

$R M S E=\left[\frac{1}{n} \sum_{i=1}^{n}\left(h_{\text {measured }}-h_{\text {calculated }}\right)_{i}^{2}\right]^{0.5}$
Setelah diperoleh model yang terkalibrasi maka dapat dilakukan simulasi model prediksi dan skenario lainnya sesuai kebutuhan sepanjang sungai. (Brunner, 2008)\& (Dias, 2004)

2 Model Potensi Pasang Surut: Skenario model ini dilakukan untuk identifikasi perkiraan luas potensi pasang surut sungai selama 15 hari di musim kemarau untuk debit andalan $\left(Q_{80}\right)$ di bulan Agustus. Pemodelan potensi ini menggabungkan $1 D 2 D$ yang mana aliran di sungai diselesaikan dengan pemodelan $1 D$ yang merupakan representasi aliran di sungai sedangkan aliran di lahan sebagai potensi (sebaran storage air di lahan) menggunakan pemodelan 2D (Ruji, 2007). Dalam pengumpulan data cross section pada simulasi 1D tidak diperoleh data cross section sampai pada dataran banjir maka data elevasi dataran banjir dilengkapi dikombinasi dengan Data DEM (Werner, 2004). Data yang digunakan untuk pemodelan 2D mengunakan data $D E M$ Alos Palsar skala 1:10.000 yang diperoleh dari LAPAN. Simulasi $1 D 2 D$ tidak sensitif dalam melakukan kalibrasi, tetapi simulasi 1D2D berperan baik untuk perhitungan storage yang merupakan potensi sumber daya air (Chatterjee et.al , 2008).
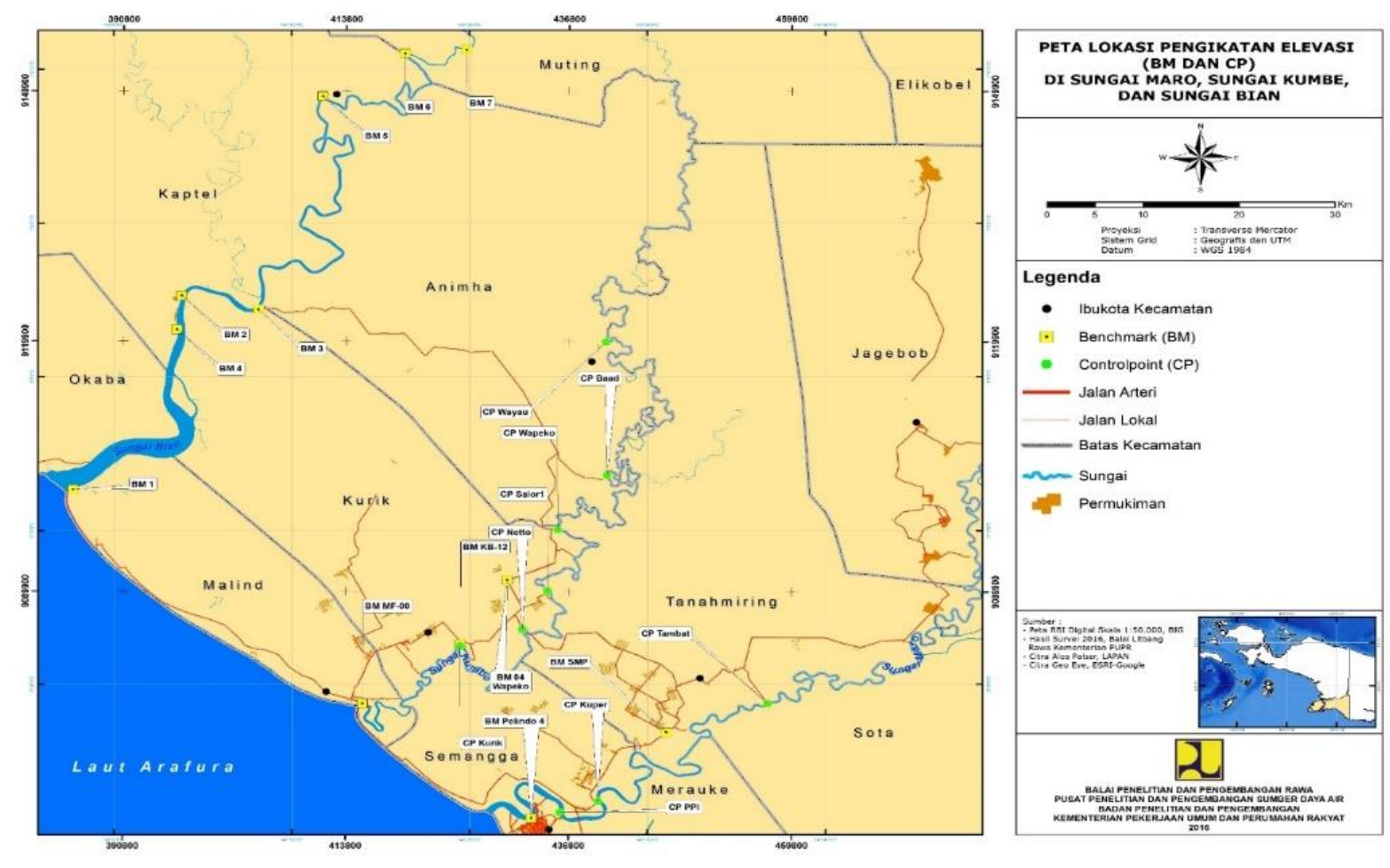

Gambar 5 Peta Lokasi Pengukuran Hidrometri Sungai 
Toleransi pemodelan potensi pasang surut pada tiga sungai dibatasi sesuai dengan toleransi ketersediaan data yang dimiliki. Ketelitian pemodelan hidrodinamika $1 D 2 D$ terintegrasi ini saling berkaitan artinya ketelitian $1 D$ akan mempengaruhi ketelitian dari luas limpasan demikian juga ketelitian $2 D$ dalam hal ini akurasi DEM. Adapun resolusi spasial dari DEM Alos Palsar Merauke tersebut adalah $5 \times 5 \mathrm{~m}$ dan akurasi vertikal $80,791 \mathrm{~cm}$ yang artinya sudah memenuhi toleransi NSSDA (National Standard for Spatial Data Accuracy) pada interval kontur 5 $\mathrm{m}$ sebesar $90,8 \mathrm{~cm}$ atau pada skala 1:10.000
(LAPAN, 2016). Sebagai batas toleransi ketelitian pemodelan maka nilai RMSE Model Kalibrasi $1 D$ harus minimal sama $(80,791 \mathrm{~cm})$ dengan ketelitian akurasi vertikal $D E M$ yang merupakan acuan untuk model $2 D$, sehingga akan dihasilkan Peta Potensi Pasang Surut di Kabupaten Merauke sesuai dengan skala DEM 1:10.000. Namun untuk mengurangi waktu simulasi data DEM untuk pemodelan banjir dapat diperkecil resolusinya sesuai dengan kebutuhan skala makro atau mikro, untuk skala mikro maka objek seperti jalan, saluran harus tetap teridentifikasi sehingga perkecilan dibatasi harus $<\sqrt{2}$ pixel (Haile, 2005).

- Waterlevel $1-$ Waterlevel $2-$ Waterlevel BM2 - Waterlevel BM3 - Waterlevel BM4 - Waterlevel BM5 - Waterlevel BM

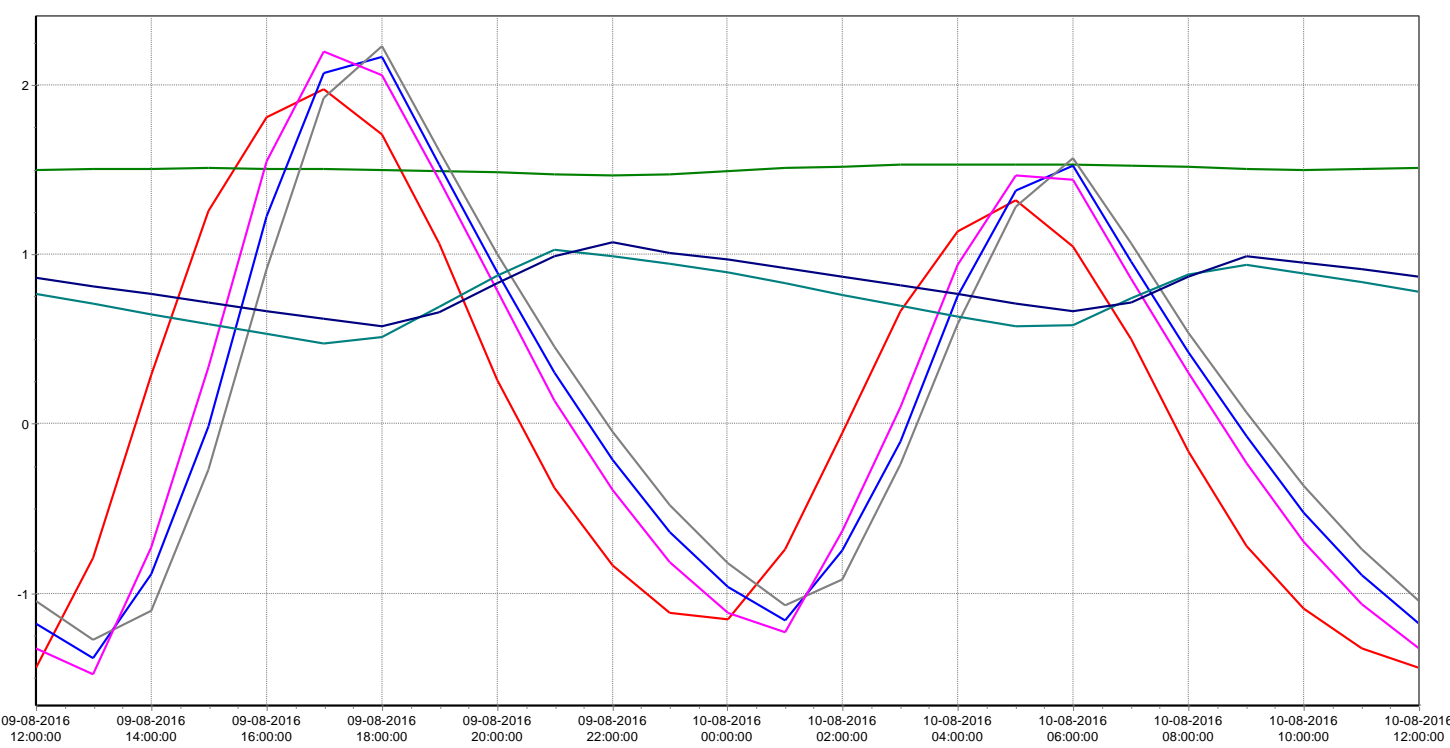

Gambar 6 Muka Air pada Sungai Bian Hasil Simulasi 1D Neap tide

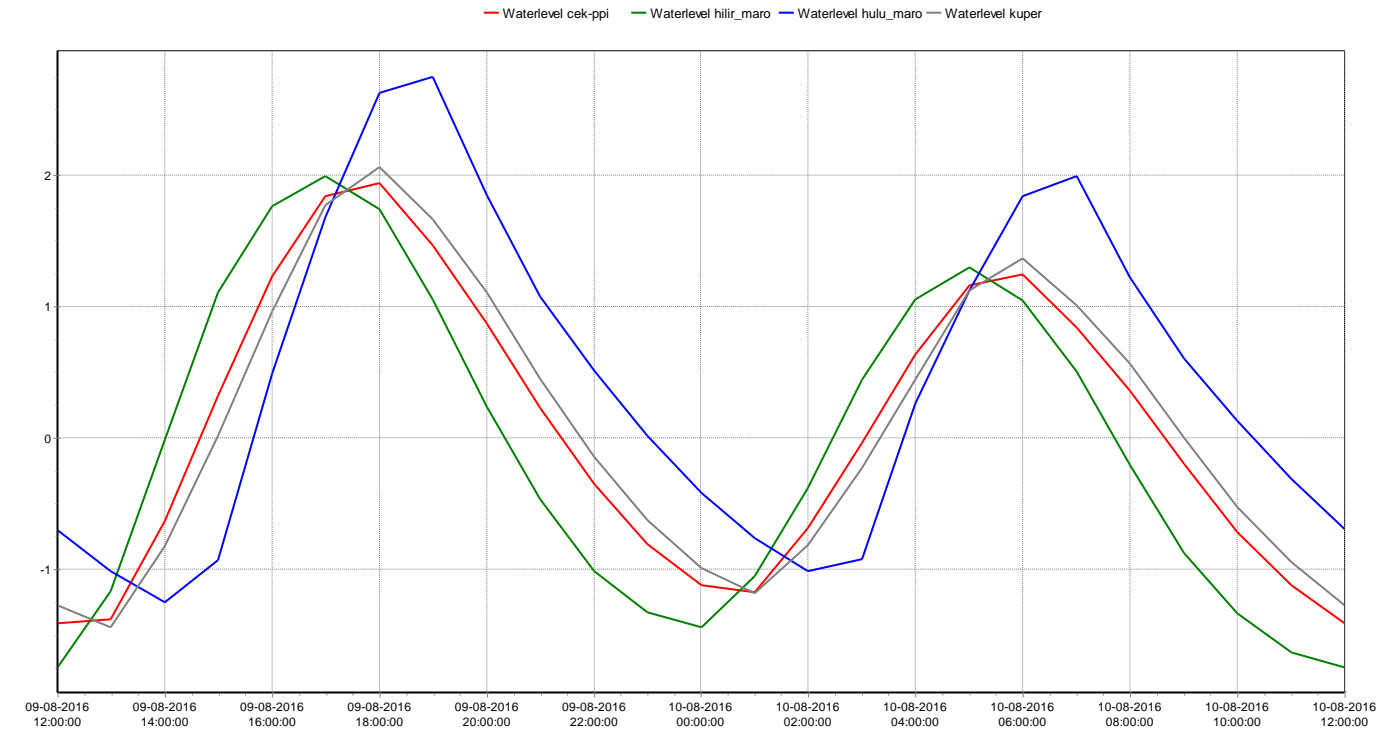

Gambar 7 Muka Air pada Sungai Maro Hasil Simulasi 1D Neap Tide 


\section{HASIL DAN PEMBAHASAN}

Sebagaimana telah diuraikan sebelumnya, studi ini menggunakan pemodelan hidrodinamika $1 D$ dengan perangkat lunak SOBEK dengan modul $1 D$ Flow Rural dan $2 D$ Overland flow. Dari hasil pemodelan saat neap tanggal 9 Agustus 2016 pukul 12:00 WIT hingga 10 Agustus 2016 pukul 12:00 WIT dilakukan pengecekan hasil model dengan muka air di lokasi yang diamati di lapangan sebagai nilai kontrol. Hasil disajikan pada Gambar 6 untuk sungai Bian, Gambar 7 untuk Sungai Maro, dan Gambar 8 untuk Sungai Kumbe.

Keterangan Waterlevel 1 merupakan $B M 1$ yang terletak di Muara dan Waterlevel 2 merupakan $B M 7$ yang terletak di hulu dengan jarak $125 \mathrm{Km}$. Adapun urutan jarak dari BM1$B M 4-B M 2-B M 3-B M-5-B M 6-B M 7$ adalah 0-26-3140-92-117-125 Km. Besarnya tunggang pasang di stasiun $B M 1-B M$ 4-BM2-BM3 hampir sama, hal ini menunjukan lancarnya perambatan gelombang pasang surut dari muara sampai ke stasiun $B M$ tersebut. Sedangkan di stasiun BM5 dan BM6 terjadi pengurangan tunggang pasang yang cukup besar, hal ini wajar karena jarak yang cukup jauh $(52 \mathrm{~km})$ dari $B M 3$ ke $B M 5$ sehingga terjadi peredaman gelombang yang sangat besar. Pada stasiun $B M 7$ pada jarak $125 \mathrm{~km}$ sudah sangat kecil efek dari gelombang pasang surut laut.

Jarak dari stasiun AWLR Pelindo yang merupakan Hilir sungai Maro berjarak 4,34 Km dari muara sungai. Adapun urutan jarak dari Hilir Maro-Stasiun PPI-Stasiun Kuper- Hulu Maro (Kampung Tambat) adalah 4-15-22-66 Km. Besarnya tunggang pasang di stasiun AWLR
Pelindo sampai Stasiun Kuper hampir sama, hanya ada perbedaan waktu disebabkan karena jarak. Hal ini menunjukan lancarnya perambatan gelombang pasang surut dari KM 4 sampai KM 22. Pada KM 66 yang merupakan batas akhir pengukuran di Kampung Tambat gelombang pasang surut masih besar. Hal ini disebabkan karena topografi $\mathrm{Km} 0-\mathrm{Km} 66$ masih relatif datar, selain itu berdasarkan hasil pengukuran debit di Kampung Tambat rata-rata debit pasang surut selama 25 jam adalah 49,283 m³ $/ \mathrm{s}$ (debit aliran) artinya besarnya dorongan dari laut menyebabkan arus pasang lebih kuat daripada arus surut (debit aliran) yang hanya mengandalkan gravitasi.

Urutan jarak dari Hilir Sungai Kumbe-Stasiun Kampung Kurik-Stasiun Jembatan Neto- Stasiun Kampung Wapeko-Stasiun Kampung BaadStasiun Hulu Sungai Kumbe (Kampung Wayau) adalah 0-28-47-78-111-171 kilometer. Besarnya tunggang pasang KM. 0 sampai KM. 28 (Stasiun Kurik) hampir sama, hanya ada perbedaan waktu disebabkan karena jarak. Hal ini menunjukan lancarnya perambatan gelombang pasang surut dari KM 4 sampai KM 28. Pada KM 47 terjadi peredaman gelombang pasang yang cukup besar dengan pengurangan nilai tunggang pasang sebesar 1,8 $\mathrm{m}$. Pengaruh pasang surut masih dirasakan sampai KM. 78 di Kampung Wapeko dengan nilai tunggang pasang $0,7 \mathrm{~m}$. Pada KM. 111 dan KM. 171 pengaruh pasang surut sudah tidak ada yang mana ini merupakan daerah rawa lebak yang lebih dipengaruhi oleh debit aliran (musim).

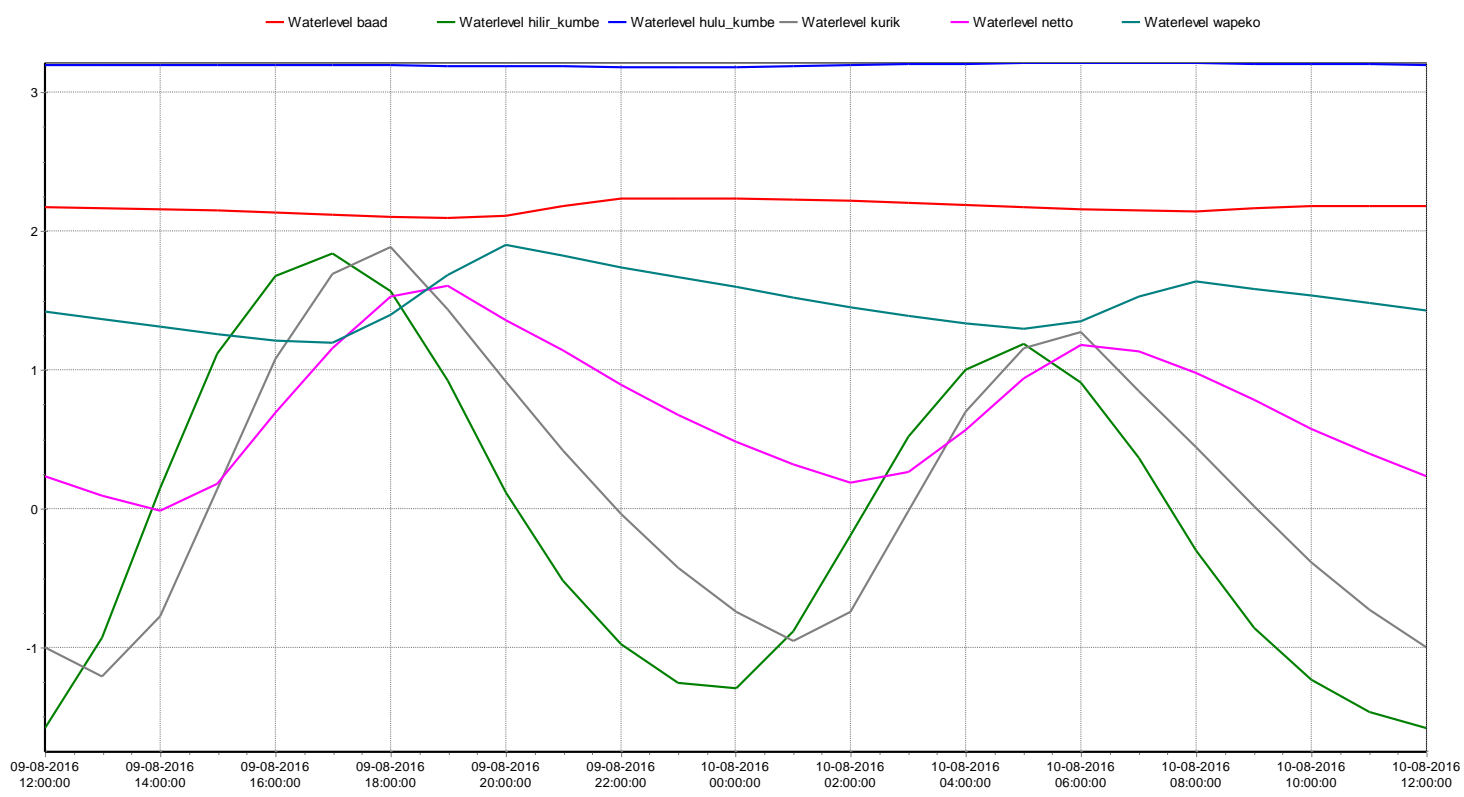

Gambar 8 Muka Air pada Sungai Kumbe Hasil Simulasi 1D Neap Tide 
Keperluan irigasi/drainase pada lahan sawah pasang surut sedapat mungkin mengandalkan pada kondisi alami pasang surut muka air di sungai yang bersangkutan, sistem tersebut sensitif terhadap data topografi dan ketinggian muka air. Dengan dilakukan rekayasa engineering ketinggian muka air di hulu menjadi potensi untuk dapat dialirkan ke daerah yang lebih rendah ketinggiannya yang dalam hal ini lokasi potensi pengembangan lahan irigasi melalui penyudetan dari Sungai Bian ke Sungai Kumbe. Namun dari hasil simulasi $1 D$ (Gambar 6,7, dan 8) diketahui tinggi muka di hulu Sungai Bian lebih rendah dari hulu Sungai Kumbe sehingga tidak dapat dilakukan penyudetan dari Sungai Bian ke Sungai Kumbe untuk menambah luas potensi pengembangan Irigasi. Penyudetan dapat dilakukan dengan mengambil lokasi outlet di Sungai Kumbe yang mempunyai elevasi muka air lebih rendah dari hulu Sungai Bian, yang tentu saja akan membutuhkan investasi yang besar (diperlukan penelitian lebih lanjut).

\section{Kalibrasi Model}

Berdasarkan simulasi hidrodinamik $1 D$ sepanjang Sungai Bian, Kumbe, dan Maro, selanjutnya dilakukan proses kalibrasi dengan membandingkan ketinggian muka air hasil model dan pengamatan di sepanjang sungai yang ditinjau, yaitu di beberapa titik yang telah ditentukan sebelumnya. Pada kasus studi ini tidak dilakukan kalibrasi kecepatan/debit aliran di Stasiun PPI pada Sungai Maro namun karena keterbatasan alat current meter pada saat pengukuran serentak tiga sungai, sehingga pengukuran kecepatan aliran hanya dilakukan di hulu yang merupakan kondisi batas hulu. Keterbatasan alat ini karena lebar sungai yang besar yang mana pengukuran kecepatan aliran minimal dilakukan di 3 vertikal secara serentak di tiga sungai (BTA 60, 1982). Idealnya pengukuran di sungai pasang surut yang merupakan sungai besar pengukuran debit dilakukan dengan ADCP (Mirfenderesk dan Tomlinson, 2007).

Pembahasan Peredaman gelombang pasang surut yang terjadi sepanjang Sungai Bian, Kumbe dan Maro disebabkan oleh Debit aliran hulu dan lateral, kemiringan dasar saluran, kekasaran (koefisien manning), saluran yang dangkal. Parameter inilah yang menjadi kunci dalam melakukan kalibrasi. Tantangan kalibrasi pemodelan hidrodinamik $1 D$ pada sungai, khususnya sungai pasang surut adalah nilai maning yang berbeda-beda pada ketinggian air yang berbeda dan berbeda pula di sepanjang sungai. Berdasarkan percobaan berkali-kali diperoleh hasil yang disajikan pada Gambar 9, 10 dan 11.

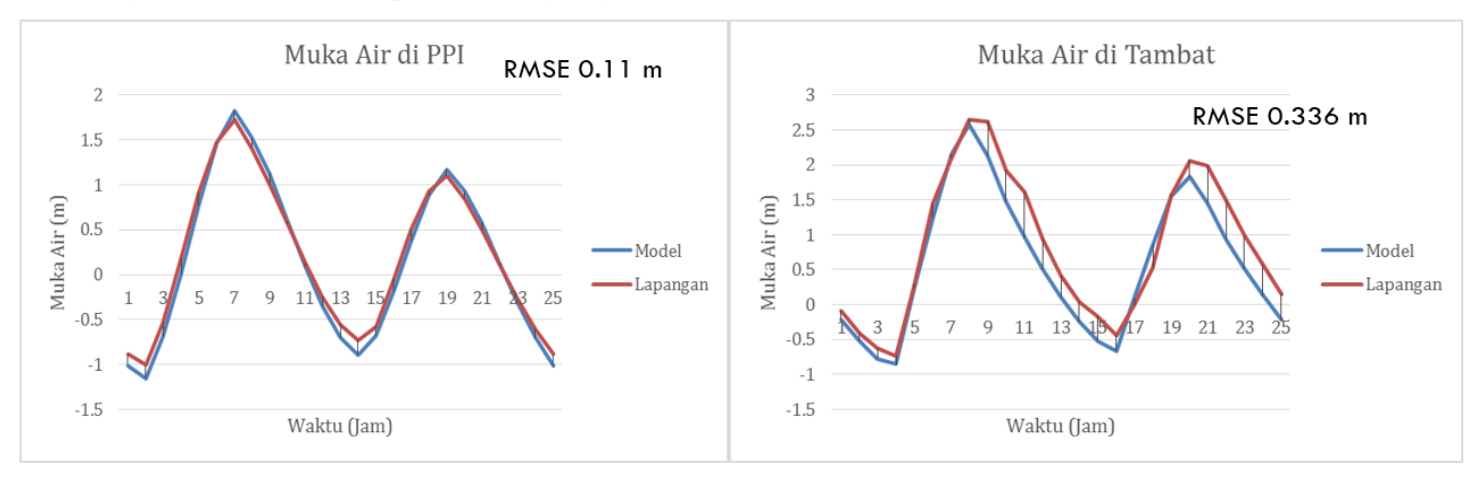

Gambar 9 Kalibrasi muka air di Sungai Maro

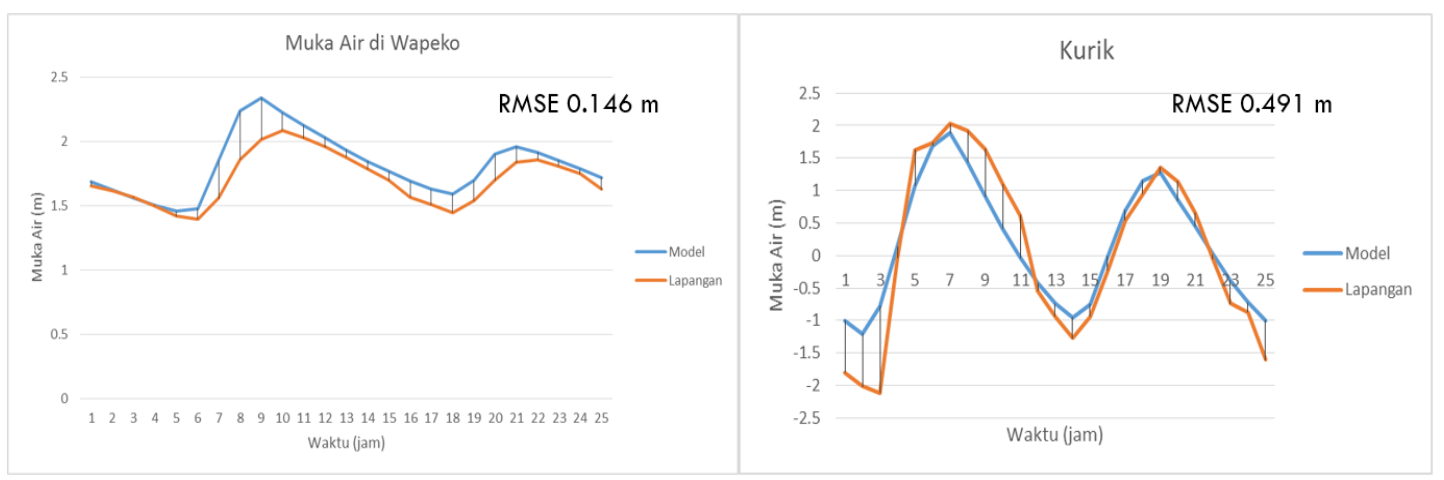

Gambar 10 Kalibrasi Muka Air di Sungai Kumbe 


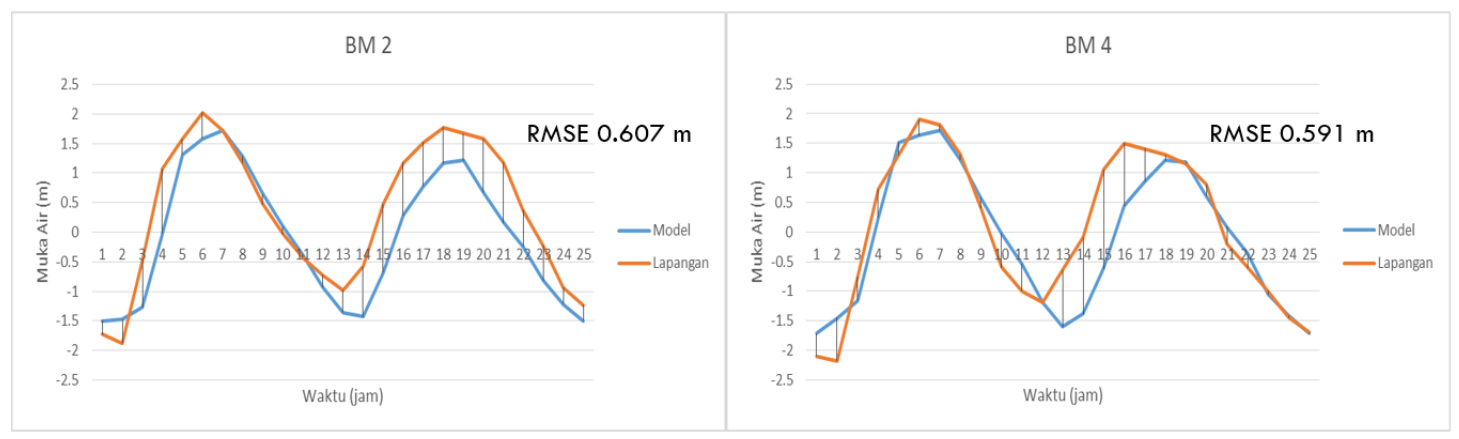

\section{Gambar 11 Kalibrasi Muka Air di Sungai Bian}

Nilai RMSE pemodelan kalibrasi di Sungai Maro rata-rata $\pm 0,223 \mathrm{~m}$, sedangkan untuk Sungai Kumbe adalah $\pm 0,381 \mathrm{~m}$ dan untuk Sungai Bian $\pm 0,599 \mathrm{~m}$. Adapun nilai kekasaran manning bervariasi pada ketiga sungai mulai dari 0,025 sampai 0,06. Jika dibandingkan dengan sungai Yelllow di China yang juga menggunakan Sobek pada wilayah estuari nilai kekasaran berkisar antara 0.007 sampai dengan 0.025 (Ji, et. $\mathrm{Al}, 2003$ ) adapun perbedaan pada simulasi ini selain karena pernedaan kondisi geografis wilayahnya simulasi pada sungai Yellow juga hanya $38 \mathrm{Km}$ dari muara sedangkan Papua sampai $171 \mathrm{Km}$ sehingga karakteristik kekasaran daerah hulu nya tidak teridentifikasi. RMSE Model Kalibrasi $1 D$ Kalibrasi pengukuran serentak di tiga sungai ini memenuhi toleransi dari akurasi nilai vertikal DEM yaitu 0,807 m. Hasil Kalibrasi di Sungai Kumbe dan Sungai Bian kurang bagus, hal ini disebabkan karena semakin ke arah Barat infrastruktur semakin terbatas dan kondisi alam semakin sulit. Selain itu juga pengukuran serentak tiga sungai harus terkoordinasi dengan baik tanpa alat komunikasi yang disebabkan tidak adanya sinyal telepon selular di lokasi pengukuran dan alat komunikasi radio hanya menjangkau $\pm 3 \mathrm{~km}$.

\section{Pemodelan Potensi Pasang Surut}

Setelah proses kalibrasi selesai dilakukan dan diperoleh parameter model yang mendekati kondisi lapangan sesuai batas toleransi, maka selanjutnya dilakukan simulasi model $1 D-2 D$ dengan kondisi batas hulu yaitu debit andalan (Q80) dan kondisi batas hilir fluktuasi muka air pasang surut selama 15 hari. Sebagaimana diketahui bahwa pemodelan $1 D$ tidak dapat memberikan informasi perilaku aliran di lahan, oleh karena itu dibuat pemodelan $1 D-2 D$ untuk melihat pola genangan alami di lahan (Chatterjee et. al., 2008). Pemodelan $1 D-2 D$ ini terhubung dengan prinsip hukum kekekalan Massa. Pemodelan SOBEK Overland Flow 2D membutuhkan komputer dengan spesifikasi tinggi dengan data DEM. Data DEM Alos Palsar
Skala 1:10.000 dengan resolusi spasial $5 \times 5 \mathrm{~m}$, dalam studi ini dimodifikasi dan direduksi menjadi resolusi spasial 100 x 100 m, namun tidak mengurangi ketelitian vertikalnya. Hal ini dilakukan karena keterbatasan komputer yang tersedia yang mana kemampuan running model amat terbatas. Untuk simulasi selama 15 hari dengan data DTM resolusi 100 x $100 \mathrm{~m}$ membutuhkan waktu 2 hari 7 jam, oleh karenanya tidak memungkinkan bila menggunakan resolusi $5 \times 5 \mathrm{~m}$.

Penggunaan debit andalan dikarenakan penerapan kebutuhan air sebagian besar untuk irigasi. Debit andalan yang digunakan adalah $\mathrm{Q}_{80}$ berdasarkan pada debit minimum sungai yang kemungkinan terpenuhi untuk irigasi yang telah ditetapkan sebesar $80 \%$ (KP Irigasi, 2010), Dalam menentukan besarnya debit andalan dengan peluang $80 \%$ digunakan probabilitas Metode Weibull, dengan rumus :

$$
P=\frac{m}{n+1} \times 100 \%
$$

dimana:

$P=\operatorname{peluang}(\%)$

$m=$ nomor urut data

$n=$ jumlah data

Berikut pada Tabel 1, 2 dan 3 disajikan data debit andalan kondisi batas hulu di Sungai Bian, Kumbe dan Maro.

Dari data rekaman selama 13 tahun terlihat bahwa debit minimum terjadi pada bulan Agustus dan September yang merupakan musim kemarau. Simulasi potensi dilakukan pada musim kemarau bulan Agustus agar diketahui potensi terkritis dari kondisi alami sungai yang dapat dialirkan ke lahan. Dari hasil pemodelan 1D2D diperoleh perkiraan luas potensi pasang surut selama 15 hari dan diperoleh perhitungan volume storage di Sungai Bian, Kumbe, dan Maro selama 15 hari seperti pada tabel 4 . 
Tabel 1 Debit Sungai Bian di Kampung Embang

\begin{tabular}{|c|c|c|c|c|c|c|c|c|c|c|c|c|}
\hline \multirow{2}{*}{ Tahun } & \multicolumn{12}{|c|}{ Debit Sungai Bian di Desa Embang $\left(\mathrm{m}^{3} / \mathrm{s}\right)$} \\
\hline & Jan & Feb & Mar & Apr & Mei & Jun & Jul & Agust & Sep & Okt & Nop & Des \\
\hline 2003 & 382,20 & 372,48 & 384,91 & 306,70 & 124,22 & 133,91 & 238,64 & 153,64 & 157,76 & 303,75 & 133,58 & 406,63 \\
\hline 2004 & 560,12 & 328,01 & 415,97 & 135,60 & 337,93 & 101,57 & 61,95 & 50,98 & 49,77 & 178,28 & 551,26 & 495,68 \\
\hline 2005 & 237,01 & 221,78 & 463,08 & 369,60 & 104,93 & 99,47 & 135,54 & 56,34 & 124,50 & 288,22 & 373,84 & 435,14 \\
\hline 2006 & 140,39 & 200,00 & 323,67 & 294,75 & 116,76 & 182,78 & 132,43 & 58,51 & 65,44 & 44,08 & 148,06 & 322,59 \\
\hline 2007 & 233,76 & 374,53 & 474,19 & 338,52 & 219,12 & 294,60 & 64,97 & 126,03 & 200,78 & 323,68 & 474,65 & 329,93 \\
\hline 2008 & 272,50 & 223,22 & 668,68 & 351,23 & 165,20 & 126,98 & 167,37 & 107,62 & 194,70 & 413,22 & 473,23 & 449,88 \\
\hline 2009 & 484,65 & 434,20 & 600,79 & 444,58 & 279,76 & 293,19 & 88,26 & 72,12 & 85,55 & 116,59 & 195,11 & 371,02 \\
\hline 2010 & 201,48 & 449,52 & 576,39 & 490,05 & 193,56 & 199,15 & 256,68 & 350,72 & 299,18 & 322,75 & 503,60 & 370,16 \\
\hline 2011 & 461,26 & 494,79 & 556,56 & 598,92 & 180,15 & 94,87 & 77,42 & 68,11 & 96,08 & 157,17 & 485,61 & 334,43 \\
\hline 2012 & 533,00 & 685,53 & 391,55 & 469,10 & 483,07 & 215,29 & 159,90 & 115,70 & 190,66 & 289,52 & 72,51 & 584,44 \\
\hline 2013 & 97,18 & 347,73 & 460,83 & 107,05 & 255,41 & 685,81 & 148,97 & 79,02 & 60,64 & 313,27 & 198,91 & 339,68 \\
\hline 2014 & 291,06 & 169,68 & 611,70 & 325,60 & 216,25 & 233,79 & 94,53 & 93,13 & 220,75 & 74,89 & 685,41 & 415,08 \\
\hline 2015 & 346,24 & 255,18 & 194,28 & 341,23 & 228,38 & 69,59 & 354,40 & 77,17 & 45,52 & 166,10 & 365,56 & 94,62 \\
\hline Q80 & 189,2609 & 217,4278 & 372,6596 & 262,9158 & 122,7268 & 98,54843 & 74,92784 & 58,07428 & 58,46554 & 108,246 & 145,1615 & 328,4651 \\
\hline
\end{tabular}


Jurnal Teknik Hidraulik Vol.9 No.1, Juni 2018: 17 - 32

Tabel 2 Debit Sungai Kumbe di Kampung Wayau

\begin{tabular}{|c|c|c|c|c|c|c|c|c|c|c|c|c|}
\hline \multirow{2}{*}{ Tahun } & \multicolumn{12}{|c|}{ Debit Sungai Kumbe di Desa Wayau $\left(\mathrm{m}^{3} / \mathrm{s}\right)$} \\
\hline & Jan & Feb & Mar & Apr & Mei & Jun & Jul & Agust & Sep & Okt & Nop & Des \\
\hline 2003 & 76,50 & 85,58 & 92,24 & 69,88 & 44,45 & 51,72 & 45,50 & 45,46 & 34,63 & 37,93 & 37,89 & 99,11 \\
\hline 2004 & 197,92 & 87,81 & 159,47 & 43,39 & 86,74 & 3549 & 27,65 & 22,71 & 21,75 & 47,18 & 108,25 & 102,34 \\
\hline 2005 & 104,75 & 76,87 & 141,70 & 106,01 & 36,66 & 32,56 & 36,95 & 22,73 & 44,38 & 58,56 & 97,03 & 146,62 \\
\hline 2006 & 58,50 & 103,72 & 126,59 & 131,53 & 55,93 & 65,72 & 40,41 & 27,44 & 24,18 & 18,16 & 39,50 & 59,37 \\
\hline 2007 & 79,48 & 80,97 & 142,13 & 131,81 & 45,61 & 56,62 & 29,57 & 42,30 & 59,16 & 77,81 & 111,81 & 102,23 \\
\hline 2008 & 84,33 & 60,00 & 218,03 & 137,34 & 45,50 & 35,94 & 48,57 & 33,82 & 50,72 & 92,17 & 123,01 & 124,41 \\
\hline 2009 & 116,42 & 149,71 & 183,10 & 141,80 & 85,31 & 70,14 & 37,36 & 32,05 & 43,37 & 43,68 & 53,30 & 97,35 \\
\hline 2010 & 67,59 & 109,62 & 202,41 & 154,89 & 59,79 & 112,90 & 79,98 & 95,79 & 94,26 & 91,20 & 124,30 & 130,45 \\
\hline 2011 & 112,25 & 172,39 & 136,44 & 229,55 & 70,16 & 44,30 & 33,79 & 28,82 & 41,04 & 45,30 & 75,79 & 70,06 \\
\hline 2012 & 195,06 & 164,29 & 144,79 & 187,22 & 113,25 & 60,93 & 58,19 & 39,95 & 37,82 & 67,79 & 27,94 & 122,58 \\
\hline 2013 & 64,82 & 175,78 & 129,17 & 42,76 & 87,37 & 163,59 & 54,15 & 40,13 & 25,84 & 60,06 & 75,67 & 91,77 \\
\hline 2014 & 155,42 & 109,99 & 221,56 & 120,89 & 49,00 & 47,82 & 32,64 & 33,03 & 36,28 & 22,52 & 122,23 & 115,44 \\
\hline 2015 & 96,55 & 82,10 & 87,49 & 182,74 & 76,28 & 30,29 & 150,85 & 28,73 & 20,51 & 52,45 & 61,76 & 44,76 \\
\hline Q80 & 67,03619 & 80,14953 & 119,7207 & 64,58222 & 45,28989 & 34,90186 & 32,02761 & 26,49877 & 23,6929 & 34,84728 & 39,17515 & 67,92457 \\
\hline
\end{tabular}


Tabel 3 Debit Sungai Maro di Kampung Tambat

\begin{tabular}{|c|c|c|c|c|c|c|c|c|c|c|c|c|}
\hline \multirow{2}{*}{ Tahun } & \multicolumn{12}{|c|}{ Debit Sungai Maro di Desa Tambat $\left(\mathrm{m}^{3} / \mathrm{s}\right)$} \\
\hline & Jan & Feb & Mar & Apr & Mei & Jun & Jul & Agust & Sep & Okt & Nop & Des \\
\hline 2003 & 223,86 & 295,13 & 266,45 & 233,82 & 152,54 & 142,07 & 138,46 & 134,68 & 94,42 & 123,39 & 154,60 & 355,56 \\
\hline 2004 & 560,70 & 297,60 & 486,59 & 212,42 & 209,40 & 117,15 & 96,78 & 80,58 & 67,72 & 139,08 & 265,74 & 402,64 \\
\hline 2005 & 338,75 & 329,46 & 441,46 & 354,88 & 123,34 & 108,95 & 141,64 & 85,31 & 138,82 & 137,34 & 297,34 & 346,22 \\
\hline 2006 & 186,43 & 283,12 & 308,55 & 314,26 & 193,76 & 248,62 & 146,39 & 94,19 & 80,18 & 61,91 & 104,51 & 198,88 \\
\hline 2007 & 214,09 & 311,99 & 506,28 & 507,81 & 155,56 & 201,99 & 110,02 & 139,50 & 175,29 & 242,00 & 331,77 & 307,33 \\
\hline 2008 & 313,07 & 232,85 & 717,92 & 442,52 & 155,25 & 128,01 & 152,09 & 127,10 & 144,15 & 233,57 & 362,90 & 479,73 \\
\hline 2009 & 458,29 & 451,69 & 812,93 & 433,54 & 270,32 & 232,91 & 130,60 & 118,95 & 160,98 & 168,86 & 280,98 & 437,15 \\
\hline 2010 & 364,70 & 487,19 & 666,40 & 546,99 & 212,61 & 315,37 & 300,81 & 318,53 & 377,29 & 295,79 & 418,44 & 435,06 \\
\hline 2011 & 330,26 & 664,24 & 506,69 & 661,97 & 222,92 & 174,78 & 146,15 & 103,13 & 114,68 & 154,84 & 237,38 & 311,08 \\
\hline 2012 & 503,18 & 630,20 & 550,62 & 592,03 & 453,50 & 228,37 & 273,75 & 154,53 & 131,20 & 230,22 & 108,98 & 263,15 \\
\hline 2013 & 348,36 & 913,42 & 909,36 & 226,18 & 381,52 & 609,78 & 208,83 & 143,79 & 101,11 & 219,36 & 297,94 & 393,30 \\
\hline 2014 & 404,57 & 466,80 & 682,89 & 801,46 & 170,26 & 152,84 & 119,10 & 129,64 & 126,31 & 84,89 & 360,50 & 300,36 \\
\hline 2015 & 333,39 & 240,62 & 253,00 & 370,02 & 192,92 & 102,79 & 448,47 & 90,49 & 70,10 & 106,72 & 216,29 & 134,62 \\
\hline Q80 & 221,9045 & 274,6166 & 300,13 & 232,2916 & 154,7041 & 115,512 & 117,2818 & 89,45355 & 78,16646 & 102,3509 & 145,4782 & 250,3 \\
\hline
\end{tabular}

Sumber: Balai Litbang Rawa, 2016 
Dari hasil tersebut diketahui bahwa nilai storage potensi pasang surut Sungai Bian, Kumbe, dan Maro sebesar 1,7 $\mathrm{Mm}^{3}$. Volume storage adalah air yang melimpas ke lahan yang merupakan pengurangan dari debit masuk dan debit keluar dalam satu sistem pemodelan. Pada model ini dimasukan parameter debit aliran anak sungai yang masuk ke sungai utama sedangkan aliran keluar dari sungai utama tidak dimasukan karena aliran debit keluar dari sungai utama akan tersimulasi dari pemodelan 1D2D. Dalam perhitungan pasti akan ada nilai eror yang mana eror hasil pemodelan adalah $85,08 \mathrm{~m}^{3}$ yaitu sekitar $4.10^{-6} \%$ dari volume storage yang artinya dapat diabaikan. Hal ini membuktikan bahwa model sudah stabil dan valid dengan dibuktikan tidak ada volume air yang negatif (Aldrighetti, 2007).

Simulasi $1 D 2 D$ menggunakan data $D E M$ yang merupakan konfigurasi bentuk asli permukaan bumi tanpa adanya vegetasi dan bangunan di atasnya. Nilai kekasaran manning untuk simulasi $2 D$ dipilih sebesar 0,02 agar diketahui potensi luas genangan pada kondisi ideal. Berikut pada Gambar 12 disajikan gambaran luasan dan ketinggian genangan di daerah pengaliran Sungai Bian, Kumbe, dan Maro.
Berdasarkan hasil simulasi SOBEK 1D2D untuk Sungai Bian, Kumbe dan Maro diperoleh luasan pada kondisi ideal daerah yang dapat digenangi adalah 123.609 ha, potensi ini adalah pada musim kemarau yang mana air sangat dibutuhkan untuk irigasi rawa, sedangkan di musim hujan petani memanfaatkan tadah hujan tanpa perlu imbuhan air irigasi. Hasil pemodelan hidrodinamika $1 D$ sepanjang sungai dapat membantu para perencana untuk merencanakan sistem tata air irigasi rawa yang terintegrasi sesuai zonasi makro rawa dan spesifik di lokasilokasi yang akan dikembangkan seperti lokasi intake air, maksimum air yang dapat dibuang, desain drainase, dan lain-lain.

Dengan target Pemerintah membuka lahan irigasi baru 1 juta hektar maka untuk dapat disalurkan ke lokasi pertanian yang membutuhkan irigasi diperlukan rekayasa engineering dengan membuat sistem tata air irigasi rawa yang terintegrasi sehingga pemanfaatan air untuk drainase dan irigasi di lahan rawa dapat optimal.

Diperlukan studi lebih lanjut di lokasi lain seperti Merauke bagian barat, Kabupaten Boven Digoel, Kabupaten Mappi dan Kabupaten Asmat sehingga target pemerintah membuka lahan irigasi baru 1 juta hektar dapat tercapai.

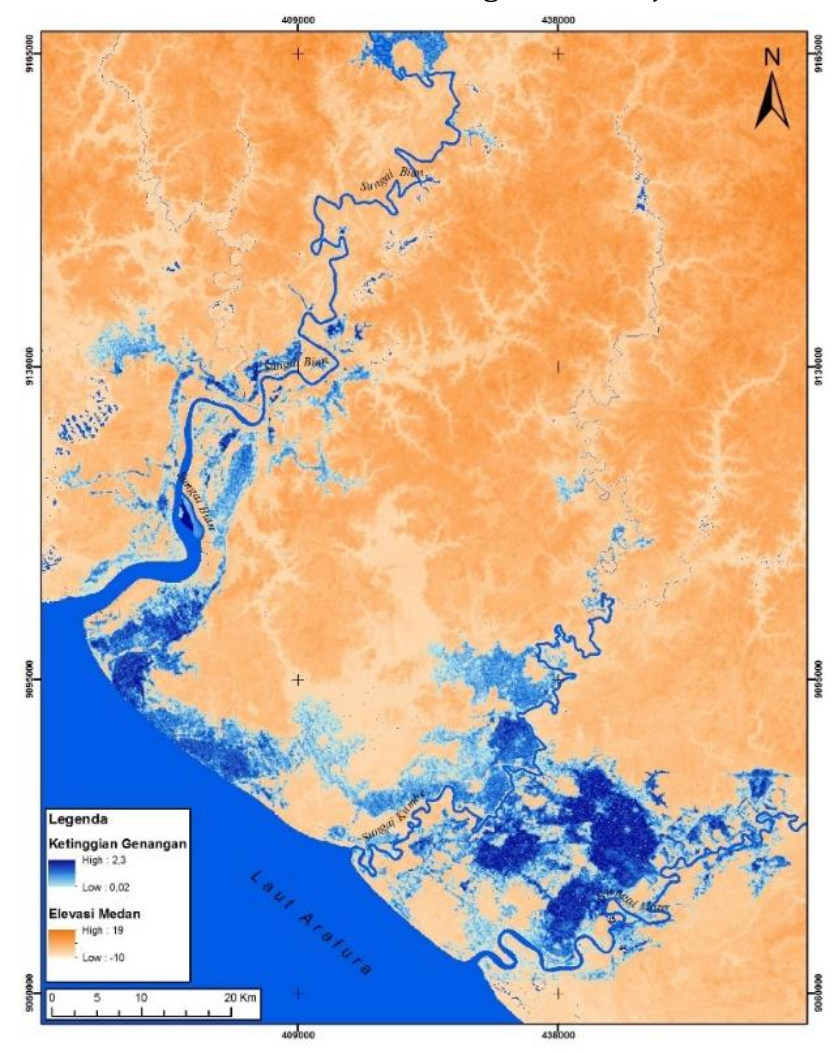

\section{Gambar 12 Gambaran Luasan dan Ketinggian Genangan di Daerah Pengaliran Sungai Bian, Kumbe, dan Maro.}


Tabel 4 Hasi Pemodelan SOBEK

\begin{tabular}{c|c}
\hline External structure & Volume $\left(\mathrm{m}^{3}\right)$ \\
\hline Boundaries in $\left(\mathrm{m}^{3}\right)$ & $3.014 .199 .881,98$ \\
\hline Boundaries out $\left(\mathrm{m}^{3}\right)$ & $1.365 .326 .986,59$ \\
\hline Structures in $\left(\mathrm{m}^{3}\right)$ & 0,00 \\
\hline Structures out $\left(\mathrm{m}^{3}\right)$ & 0,00 \\
\hline Lateral disch. in $\left(\mathrm{m}^{3}\right)$ & $86.353 .343,95$ \\
\hline Lateral disch. out $\left(\mathrm{m}^{3}\right)$ & 0,00 \\
\hline Storage $\left(\mathrm{m}^{3}\right)$ & $1.735 .226 .154,26$ \\
\hline Error $\left(\mathrm{m}^{3}\right)$ & 85,08 \\
\hline
\end{tabular}

Sumber: Balai Litbang Rawa, 2016

\section{KESIMPULAN}

Kesimpulan dari hasil analisis Potensi Pasang Surut untuk Pengembangan Lahan Irigasi Rawa di Merauke adalah Nilai RMSE Pemodelan Kalibrasi di Sungai maro rata-rata $+0,223 \mathrm{~m}$, sedangkan untuk Sungai Kumbe adalah $+0,381 \mathrm{~m}$ dan untuk sungai Bian $+0,599$ m. RMSE Model Kalibrasi $1 D$ Kalibrasi pengukuran serentak di tiga sungai ini memenuhi toleransi dari akurasi nilai vertikal DEM yaitu $0,807 \mathrm{~m}$.

Berdasarkan hasil simulasi SOBEK 1D2D diperoleh luasan pada kondisi alami daerah yang dapat digenangi adalah 123.609 ha, potensi ini pada musim kemarau yang mana air sangat dibutuhkan untuk irigasi rawa. Luasan ini masih belum mecukupi target pemerintah untuk membuka lahan irigasi baru 1 Juta $\mathrm{Ha}$, maka diperlukan sumber air dengan skenario engineering untuk mencukupi kebutuhan air irigasi-nya. Dari hasil simulasi $1 D$ ketiga sungai diketahui tinggi muka di hulu Sungai Bian lebih rendah dari hulu Sungai Kumbe sehingga tidak dapat dilakukan penyudetan dari Sungai Bian ke Sungai Kumbe untuk menambah luas potensi pengembangan Irigasi.

Diperlukan studi lebih lanjut untuk dapat memenuhi kebutuhan air irigasi guna mewujudkan pembukaan lahan irigasi rawa 1 juta hektar, namun dari hasil pemodelan hidrodinamika $1 D$ sepanjang sungai Bian, Kumbe dan Maro sudah dapat membantu para perencana untuk merencanakan sistem tata air irigasi rawa yang terintegrasi sesuai zonasi makro rawa dan spesifik di lokasi-lokasi yang akan dikembangkan seperti lokasi intake air, maksimum air yang dapat dibuang, desain drainase, dan lain-lain.

\section{UCAPAN TERIMA KASIH}

Ucapan terima kasih disampaikan kepada Balai Litbang Rawa dan Balai Litbang HITA atas ijin penggunaan data dan informasi yang sangat membantu penyelesaian makalah ini.

\section{DAFTAR PUSTAKA}

Aldrighetti, E. 2007. Computational hydraulic techniques for the Saint Venant equations in arbitrarily shaped geometry, (May), 125.

Alihamsyah, T. 2004. Potensi dan Pendayagunaan Lahan Rawa untuk Peningkatan Produksi Padi. Bogor, Jawa Barat, Indonesia.

Badan Pusat Statistik Kabupaten Merauke. 2016. Kabupaten Merauke Dalam Angka 2016. Merauke: BPS Kabupaten Merauke.

Balai Litbang Rawa. 2016. Laporan Akhir Pengembangan Lahan Irigasi Rawa di Papua. Pusat Litbang SDA. Balitbang Kementerian Pekerjaan Umum dan Perumahan Rakyat

Balai Wilayah Sungai Papua, 2015, Presentasi Potensi Papua, Dirjen Sumber Daya Air, Kementerian Pekerjaan Umum dan Perumahan Rakyat

Ballesteros, J. A., Bodoque, J. M., Díez-Herrero, A., Sanchez-Silva, M., \& Stoffel, M. 2011. Calibration of floodplain roughness and estimation of flood discharge based on tree-ring evidence and hydraulic modelling. Journal of Hydrology, 403(1-2), 103-115. https://doi.org/10.1016/j.jhydrol.2011.03.045

Brunner, G. W. 2008. Calibration of Unsteady Flow Models, 10(May), 1-42.

Chatterjee, C., Frster, S., \& Bronstert, A. 2008. Comparison of hydrodynamic models of different complexities to model floods with emergency storage areas. Hydrological Processes, 22(24), 4695-4709. https://doi.org/10.1002/hyp.7079

Daniel L. Mendelsohn, Steven Peene, Eduardo Yassuda, S. D. 1999. A Hydrodynamic Model Calibration Study of the Savannah River Estuary with an Examination of Factors Affecting Salinity Intrusion Daniel. Proceedings of 6th International Conference on Estuarine and Coastal Modeling., 663--685.

Dias, J. M., \& Lopes, J. F. 2006. Implementation and assessment of hydrodynamic, salt and heat transport models: The case of Ria de Aveiro Lagoon (Portugal). Environmental Modelling and Software, 21(1), 1-15. https://doi.org/10.1016/i.envsoft.2004.09.002 
DPMA. 1982. BTA 60. Laporan Survei Hidrometri Sungai Maro Irian Jaya. Direktorat Penyelidikan Masalah Air. Departemen Pekerjaan Umum.

Direktorat Jendral Sumber Daya Air, 2010, Standar Perencanaan Irigasi, Kriteria Perencanaan, Kementerian Pekerjaan Umum

Haile, A. T., \& Tamiru Haile, A. 2005. Integarting Hydrodynamic Models and High Resolution DEM (LiDAR) For Flood Modelling. Itc, 53(9), 16891699.

https://doi.org/10.1017/CBO9781107415324.00 4

Ho, W., \& Minh, C. 2011. Tutorial SOBEK-Rural.

Ji, Z., Vriend, H. de, \& Hu, C. 2003. Application of Sobek Model in the Yellow. International Conference on Estuares and Coasts, 909-915.

Lapan. 2016. Laporan Akhir Penyusunan Informasi Spasial Berbasis Data Satelit Penginderaan Jauh (Penutup Lahan, Digital Terrain Model Dan Lahan Gambut)

Las, Irsal, Et Al. 2007. "Water Availibility For Agriculture Sector: Challenges And Resolution Strategy." Badan Litbang Pertanian. Kementrian Pertanian.

Lasmana, Yudi, 2012, “Evaluasi Kinerja Polder Pluit Skenario Banjir 2007", Tesis MPSDA Institut Teknologi Bandung

Lasmana, Yudi, 2003,"Laporan praktikum analisis pasang surut", ITB.

Matte, P., Secretan, Y., \& Morin, J. 2017. Hydrodynamic Modeling of the St . Lawrence Fluvial Estuary . I: Model Setup, Calibration, and Validation, 143(5), 1-15. https://doi.org/10.1061/(ASCE)WW.19435460.0000397.
Mirfenderesk, H., \& Tomlinson, R. 2007. Numerical Modelling of Tidal Dynamic and Water Circulation at the Gold Coast Broadwater, Australia. Journal of Coastal Research, (February), 277-281.

Moftakhari, H. R., Jay, D. A., Talke, S. A., Kukulka, T., \& Bromirski, P. D. 2013. A novel approach to flow estimation in tidal rivers. Water Resources Research, 49(8), 4817-4832. https://doi.org/10.1002/wrcr.20363

Ruji, E. M. 2007. Floodplain inundation simulation using $2 \mathrm{~d}$ hydrodynamic modelling approach. Simulation.

Samuel, 2012, Penentuan Chart Datum Pada Sungai Yang Dipengaruhi Pasang Surut (Studi Kasus: Teluk Sangkulirang, Kalimantan Timur)), Itb Https://Digilib.Itb.Ac.Id/Gdl.Php?Mod=Browse\& $O p=$ Read\&Id=Jbptitbpp-Gdl-Samuelnim1-22733

Toffolon, M. 2002. Hydrodynamics and Morphodynamics of Tidal Channels. Dip. Ingegneria Civile E Ambientale, Ph. D. (JANUARY 2003), 173.

Triadi L. B., 2013. Pengendalian Drainase Jaringan Tata Air Sungai Sunter-Item-Sentiong Dki Jakarta, Prosiding Pertemuan Ilmiah Tahunan HATHI XXX, Jakarta

Tuoi, V. T. N. 2008. One Dimensional Saint-Venant System, (June), 46.

Werner, M. G. F. 2004. A comparison of flood extent modelling approaches through constraining uncertainties on gauge data. Hydrology and Earth System Sciences, 8, 1141-1152. https://doi.org/10.5194/hess-8-1141-2004 